\title{
God's self-revelation in the Old Testament and African concepts of God
}

\author{
J.A. van Rooy \\ Department of Old Testament \\ Hammanskraal Theological School / PU for CHE \\ POTCHEFSTROOM
}

\begin{abstract}
This article has a wofold purpose: Firstly, to demonstrate that, contrary to what has been written about the subject so far, there is not only a single, generally valid concept of God in Africa, but that at least six models of concepts exist: God as an impersonal power, or as the first ancestor, or as the far-away Creator-King, or as the benevolent cosmic Grandfather, or as a transcendental, involved God, or as one of a pantheon. Secondly, the purpose of this article is 10 demonstrate that all these models, except to a cerlain degree the fifth one, differ radically from what God reveals about himself in the Old Testament, since he is a personal God, not part of creation, not genealogically related to man, yet near in his fellowship with man, but that he also judges those who sin against his will. Finally, he is unique.
\end{abstract}

A contribution of paramount importance that Prof. Helberg has made to the theological study of the Old Testament, is certainly the approach in his publications on the history of God's revelation in the Old Testament. He takes as his point of departure the theme of the Kingdom of God, which he defines as the sovereign rule of God in intinate covenant relationship with fallen man (Helberg, 1976:2). Any one who knows Helberg personally, also knows that this personal relationship is to him no mere theological theory, but that it is a reality, the guiding principle of his life. It is therefore a privilege for me as one of his students to dedicate this study to him, and to demonstrate in it what relevance his viewpoint on the revelation of God in the Old Testament has for theology in Africa.

\section{Introduction}

Many African as well as European theologians defend the viewpoint that the Old Testament does not really have anything to teach the people of Africa which they do not already know from their own knowledge of and beliefs in God (Inkatha, 1980:40, 69), or even by implication: that Christians have a distorted view of 
God and that they can learn from traditional African religion what God really is (Setiloane, 1986:23). I therefore intend to demonstrate in this article that there is an essential difference between the Old Testament revelation about God and the views of African peoples.

It would be a fallacy to generalize about 'the African idea of God', as if there were a more or less uniform idea of the deity in African Traditional Religion. Recent studies have pointed out that there are more than one concept of God in Africa.

One should, of course, realise that within one people with a more or less homogeneous concept of God, there are usually many variations from person to person, or between families, depending on personal reflection or lack of it, the influence of Christian beliefs, or the traditions of the particular family in which a person grew up. This is also the case among Western Europeans, as any informed person can testify. Even among Afrikaans-speaking Christians, one might find individuals with a thoroughly biblical concept of God next to the occasional fanatic for whom God is still a sort of tribal god of the Afrikaans people (Scholtz, 1994). The African view of God is characterized by ambiguity. While there are differences between tribes - often in the same tribe - one can find a variety of views. Moreover, the lines of demarcation are not always clear in any given individual (McVeigh, 1974:18).

From the various concepts of God that present themselves in these studies, at least six basic models can be distinguished, which I intend to discuss further on. However, there is another aspect of African cosmology which has to be discussed first in order to grasp the nature of African 'theology'.

\subsection{The hierarchy of forces}

The people of Bantu Africa see totality as a hierarchy of forces. If one could, by means of illustration, use the figure of a ladder, God would be the highest rung of the ladder. The first ancestor or chief would be directly under him, followed by his descendants in order of seniority. The living on earth would follow the recently deceased, down to the most insignificant living person. Every being, every person, is assigned its or his proper place on the ladder. Hannony, shalom, means knowing and accepting one's place in totality and living in accordance with it (Tempels, 1946:32-38).

This concept is of great importance for understanding the ideas of God in Africa, as will be illustrated below. This concept furnishes a common factor in the variety of concepts, and that is the factor of remoteness and inaccessibility. Whether God is conceived as the first ancestor or the absolute Creator of the world, he stands on the top nung of the ladder and, like a great chief, is not naturally accessable to common people, who are near the bottom of the hierarchical 
ladder. "Neither the tribal king nor God are to be bothered with the petty problems of men" (McVeigh, 1974:35).

Before I discuss the various concepts of God found in Africa, it is also important to note that in many cases the structure of a society is reflected in its concept of God. Where the kingship is strong, and the king is hedged about with divinity and only to be approached through a hierarchy of underlings, it is natural that the Lord of the universe should be thought of as a remote chief with whom communication is possible only through intennediaries. Where the goveming functions are to some degree delegated, the atmosphere is favourable to the growth of departmental gods, one having to do with war, another with fertility, and so on (Smith, 1950:15).

\subsection{Modimo - the all-pervading, impersonal energy of life}

Yaliwel, who reveals himself in the Old Testament, is a personal God, with a personal, moral will - a God who loves his people (Deut. 7:8), feels compassion for them (Ex. 3:7; Is. 63:9), rejoices over them (Jer. 31:20), can be grieved by their conduct (Is. 63:10), and hates his enemies (Mal. 1:3). His will as well as his love is revealed in his sovereign decree to elect a people for himself (Deut. 7:7, 8). He concludes a covenant of grace with his people with the purpose of having intimate, personal fellowship with them, as a Person to persons. He calls himself their Father (Is. 1:2; Mal. 1:6), and finally becomes man in his Son Jesus Christ.

I have heard many Basotho and Batswana contesting the ideas of Setiloane that Modimo is an impersonal force. It is very difficult to be sure who is right. Setiloane, however, founds his theses on thorough research and documentation from the time when Christian missionaries first started investigating the Tswana/ Sotho concept of God, whereas those who disagree with him found their objections mainly on their own observations from contemporary beliefs and on their personal perceptions, which one can expect to be strongly influenced by the biblical idea of God. The Batswana are reputed to be nominally $95 \%$ christianized (Kritzinger, 1988:67). To those who disagree with Setiloane, the question could be asked: Why have the Basotho never objected to the use of impersonal concords and pronouns to refer to Modimo?

In any case, Setiloane's perception of the nature of Modimo is not an isolated instance, but is a model for quite a number of instances from other African pcoples, which we shall refer to after having discussed Setiloane's views. Smith (1950:21) affirms that he had no hesitation in saying that the religious beliefs and philosophy of the African are fixed primarily on the concept of a universal Power or Energy, which infonns and is the cause of all life. "This spiritual force consists of an abstract Power or natural potency, all-pervasive and definitely never regarded anthropomorphically" (Smith, 1950:21). 
It will be easy to prove that Smith is wrong in writing about 'the African' as if there were only one concept of God in Africa, but as far as the Sotho/Tswana and a number of other tribes are concerned, what he writes accords with the views of Setiloane. Further on in the same study, Smith (1950:33) affirms his own observations from many peoples, that God is to the Africans primarily Power - the Power working in things, above and below.

If there is one cardinal aspect of the Sotho-Tswana image of God about which Setiloane is adamant, it is that Modimo is not a person. In his book he constantly refers to Modimo as it.

As borne out in our analysis of the word in Sotho-Tswana MODIMO was never conceived of as a 'person'. It was understood to be something intangible, invisible, a natural phenomenon able to penetrate and percolate into things (Setiloane, 1986:27).

One of the motivations for Setiloane's study is to demonstrate that the African concept of God is quite different from the biblical one. The following quotations shed an interesting light on his relativistic view of religion and revelation:

Indeed, a major motivation for this research is that, while Christian theological study filled out my western concept of God, that concept seemed increasingly to be alien from my experience of MODIMO mediated by my own Christian, yet still radically Sotho-Tswana, upbringing (Setiloane, 1976:79).

It is the missionaries who injected into the Modimo concept of BaTswana the idea of 'Person' (being) and 'father'! (Setiloane, 1986:23).

When describing the Sotho-Tswana view of God in more specific terms, Setiloane writes, "Modimo is 'selo se se boitshegang; sa poitshego, se se tshabegang, se se mashwe' (a fearful, awful, ugly, monstrous, weird, uncanny, numinous thing)" (Setiloane, 1976:84; 1986:22). "But all these are not derogatory words," says Setiloane. "Instead, they convey as the word boitshegang does, numinousness, unapproachability, taboo, Holiness" (Setiloane, 1986:25).

There are a number of other peoples whose concepts of God are very similar to that of the Basotho. One of those is the Shangana-Tonga group with their concept of Tilo. "Above these gods which the ordinary people know, 'worship' and call by name", says Smith (1950:112-113), "there exists a Power which for the majority remains ill-defined and anonymous". "They call it (or him) Tilo ... Tilo", says Junod, "is not only an immense, solid vault which rests on the earth: it is a 'spiritual principle'... It is a power which acts and manifests itself in various ways. It is sometimes called hosi, a chief, a lord ... This power, however, is generally regarded as something entirely impersonal" (Junod, 1962:431). 
About Jok, God as perceived by the Lango of Uganda, Mbiti writes (1970:17):

The Lango consider God to be a neutral power, permeating the universe, neither well nor badly disposed towards mankind, unless made use of by man.

Perhaps McVeigh (1974:16) is right when he quotes Smith as writing:

We have seen that the Bantu believe the world to be permeated by hidden mysterious energies, and it would seem that many of them do not already distinguish God from these; to them God is the power that works in and from the sky.

\subsection{INkosi yeZulu - the far-away, uninvolved God}

Cullen Young (1950:53) remarks about the Ngoni of Northern Malawi:

I have very often felt, when listening to Christian Ngoni prayers and hymns and comparing them with the Tumbuka, Chewa or Tonga, that both tone and phraseology of approach are markedly less touched with what I can only describe as the warmth of simple trust ... I have felt that the idea of great kingship as interpreted by a fighting, and conquering people has to some extent hardened the line of the mental picture.

In saying this, Cullen Young endorses the remarks of Smith himself about the idea of God often being a projection of the structure of society.

What the Ngoni carried with them to Northern Nyasaland were titles indicative of shear power: uNkurunkuru, uNkurumnqango, uTixo, iNkosi. Behind each and all the king as autocrat seems to be implied and there is, I think, much less implication of a thoughtful concern, with implied sympathy for man, than in the Chrula and Mulungu ideas (Cullen Young, 1950: 53).

The Ngoni are closely related to the Nguni peoples of Southern Africa, and the same observations may be made about their idea of God. This is how the Nguni conceive God. Berglund (1976:32-51) describes how the Zulu think about him:

'We wonder what he is like and what he is going to do.' 'I think of him as I would think of Dr Verwoerd in Pretoria. I have no direct interest, but I think of him because I live under his rulership.' 'I know that he is there (in the sky), but I know nothing more about him. So how can I think of him. when I know nothing about him. He does not appear to us at night (i.e. in dreams). We simply hear people talking softly sometimes, whispering that he has shown himself in that somebody has been taken (i.e. struck by lightning). That is all we know of him.' Another informant said: 'We do not love him as we love the shades. He is too far away to love. One can only love the one that is near. But we fear him ... He has amonrala (a 
haphazard way of acting). So I speak correctly when I say that one cannot love one who is not trustworthy. He is not trustworthy in that we do not know what to expect of him' (Berglund, 1976:42).

Mbiti (1970:27) quotes the Zulu people saying, "We know nothing of his mode of life, nor the principles of his government. His smiting is the only thing we know".

When reading this, one is immediately reminded of the covenant faithfulness of God as revealed in the Old Testament. He does not have amowala. He can be trusted, not only in his covenant of grace, but also in his covenant with mankind with regards to nature, as revealed in the report about the covenant with Noah. See Genesis 9, especially verses 8-17.

INkosi yeZulu can be approached through the shades, as is done annually at the Umkhosi festival (Mbiti, 1970:43). In exceptional circumstances, such as times of severe drought, when the prayers to the shades have produced no results, local chiefs or persons of special authority may approach him directly, as described by Berglund (1976:45).

Monica Hunter (1961:269) wrote about the Pondo:

There is no proof that the Pondo, before contact with Europeans, believed in the existence of any Supreme Being, or beings, other than the amathongo. They had two words, umdali (creator, ukudala, to mould, to form) and umenzi (maker: ukwenza, to make), which might suggest a belief in a creator, but there is no system of rites or complex of beliefs connected with these words.

The name used by Christians for God is uThixo, which was derived from the Hottentot word for God. The fact that it was deemed necessary to use a word of foreign derivation indicates that there was no indigenous Xhosa word which seemed to the first Xhosa Christians to be suitable for referring to God. It seems as if the Xhosa people had known and used this name even before the arrival of the first missionaries. According to Hunter (1961:270), all Pondo, even those who have not come under direct Christian influence,

... assert positively that they have always known the word uThixo, and that they always called upon $u T h i x o$ when they sneezed, when they were saved from danger (as in a battle), and when laying a stone upon the isivivane... Deformed births are attributed to uThixo. Of a deforned person it is said udaliwe ngoThixo (he was created by uThixo), and an insane person is called umniu kaThixo (the person of uThixo) ... As with the other words which might imply belief in a Supreme Being there is no system of beliefs or practices associated with inkosi yezulu. 
The same applies to the High God Kyumbi of the Pare people in Tanzania; they know nothing about him except that he is the Creator of all things; beyond that he is not interested in them nor they in him (McVeigh, 1974: 49).

The fact that disasters such as deformed births and being struck by lightning is regarded as manifestations of God, suggests that it is believed to be dangerous if he, as the highest in the hierarchy of forces, approaches the lesser forces such as man. The Konde people of Malawi regards any sign of nearness or involvement in their lives by Kyala, the High God, as highly dangerous and undesirable. One of the few prayers ever directed to Kyala is one in which he is asked to go away and leave them alone: "Go far from here, O God. Go to the Sango, because your house is great" (McVeigh, 1974: 94).

Hierarchical order is strictly maintained among Bantu people. One usually communicates with another person next to oneself in the hierarchy of forces, not with those who are far above one in that hierarchy. Disregarding the intermediate rungs of the ladder and communicating directly with someone separated from one by a number of rungs (to use the metaphor again), is usually taboo. It is regarded as disregarding the hierarchy of forces. 'Water does not run past a hole', the proverb goes.

This implies that, if God is the highest rung of the ladder, and ordinary living people among the lowest rungs, it is highly irregular and very dangerous for them to have direct access to him. Nonnally he can only be approached through a whole series of mediators, such as the ancestor spirits, or via the living chief.

To this point of view one must compare the very prominent Old Testament teaching about the neamess of God. He speaks to Abraham personally (Genesis 12 and passim), pays him a visit in the company of two other heavenly beings, discusses with him the judgement on Sodom and Gomorralı (Genesis 18), just as he used to visit his children in the Garden of Eden before the Fall (Genesis 3). His word, his commandments, are not far from Israel, on the other side of the sea or up in the sky. "No, it is here with you. You know it and can quote it, so now obey it" (Deut. 30:11-14). Jacob (1958:32) says of the most prominent themes of the Old Testament, "Two closely connected themes have come to our notice more forcibly than others, the themes of the presence and the action of God".

\subsection{The indulgent cosmic grandfather}

The Venda people have a proverb which says, 'Grandfather is an ant-hill. We climb on it in play'. This proverb expresses the patience and endless indulgence of grandparents. To many Africans, this is what God is like. This view ofien permeates the others mentioned here, whether that of Modimo, the impersonal force, or of Mwari, the first chief or ancestor, or even of Leza, the personal, 
transcendent God. Smith's observations about the role of Leza in the lives of people seem to differ somewhat from those of Hopgood. He says, "That Leza should take cognisance of all the doings of men, and regard them with approval or disapproval, is an idea quite foreign to their minds. In all their invocations of Leza there is no confession of sin" (quoted in McVeigh, 1974:92). "God will never create a person and then reject him or her", is the comfort often offered on funerals, whether Christian or pagan, and whether the dead used to be a believer or not. Smith affirms this when he writes that "God is so good and kind that he never sends trouble or distress, and therefore men have no need to fear and propitiate him" (quoted in McVeigh, 1974:63). This concept is fairly wide-spread but not universal; therefore I mention it as a separate concept of God.

The Old Testament very clearly reveals that God judges his people. When man sins for the first time, he is called to account and punished (Genesis 3 ). The flood is God's judgement on the depravities of humankind, as is the battles of Joshua and the Israelites on the sins of the Canaanites. The wars of the Arameans against Israel, the exile to Assyria and the exile of Judah to Babylonia, is God's punishment and judgement on his people. He will finally judge all peoples (Isaiah 24 , to mention but one instance).

\subsection{Mwari - the first ancestor-chief}

Here we take Mwari as a model, he being the typical model for the concepts of God of quite a large number of peoples, such as the Akan:

God is not the wholly other but the 'Great Ancestor', 'the trunk of the tree from which man is a branch', so that Akan religion is in a sense 'the worship of the race' (McVeigh, 1974: 28).

This is the image of God among the Venda and some of the Shona peoples. The Venda refer to God as either Raluvhimba or Mwali. It would appear that Raluvhimba was originally a skygod, as is indicated by his name, which means, "the father of the African lanner', who flies faster than the lanner. But at present all Venda, when asked about it, state that Raluvhimba and Mwali is one and the same.

Mwari is not quite as remote as INkosi yeZulu of the Nguni peoples. There is still a cult of Mwari practised by the Shona at the Matopo Hills near Bulawayo in Zimbabwe. Previously the Venda chiefs also used to send delegations with offerings to that place.

Mwari's close association with the apex of the ancestral world has contributed both towards His anthropomorphic image and has made Him the transcendent God, the One Above. Had it not been for the oracular shrines $\mathrm{He}$ may have become as remote as some of the other African highgods (Daneel, 1970:17). 
Many Shona people actually distinguish between Mwari waMatonjeni (Mwari of the Matoppos) and Mwari we Denga (the Heavenly Mwari). Schutte (1978:112, 114) also states as the conclusion of his research, and referring specifically to the Ngomalungundu legend, that Mwali is the Ancestor God of the Vhasenzi and Vhakalanga, the first great king of the Vhasenzi, who later moved into Venda and subjected the local peoples. Mwali is also supposed to have visited the Venda people at Haluvhimbi in Eastern Venda, at Musekwa, Mudzivhadi and in the country of the people of Tshivhula near the Saltpan (Schutte, 1978:119, 120).

The same type of concept is found annong the Lozi, about whom Smith (1950:2728) writes:

His immanence is expressed symbolically in stories such as those of the Balozi about how Nyambe, while he still was living among men on earth. married several wives and by them begat children who became the nations which differ in appearance, language and custom.

Strangely enough, among a Nguni people like the Swazi is to be found the same kind of idea in the belief about Umkhulumncandl. Of him Hilda Kuper (1947: 191) writes, "Umkhulummcandi is an otiose Great Ancestor (Lidloti lelikhulu)".

According to Mbiti (1970:114), the Edo people of Nigeria also inagine God (Osa) to be a king with many wives and children, living in great splendour.

It seems that among the Zulu the idea of God is not quite consistent. On the one hand there is INkosi yeZulu, the remote God who has never been human and is not related to man. On the other hand there is the idea of UMvelingqangi, who can be compared to the Swazi Umkhulumncandi, and is reputed to have a wife and children (Mbiti, 1970:114).

When comparing these ideas to the revelation about God in the Old Testament, two observations should be briefly made here. In the first place there is no trace of the idea that God is or ever has been genealogically related to man. He is always the sovereign Creator, which by that fact is sui generis, essentially different from man.

In the second place, when God is referred to as Father in the Old Testament, that refers to his authority, and to his election of Israel, and no genealogical relationship is implied (Keil, 1875:458).

\subsection{Leza of the Tonga/lla: theism in Africa}

If ever there were a concept of God outside the sphere of revelation in Scripture which closely corresponds to that of the Old Testament, that concept would be the idea that the Tonga people of Zambia have of God. According to Hopgood (1950:74) 
... the Tonga conceptions of God ... have much in common with the thought of the Old Testament, especially with the conception of God as the AllPowerful transcendent Being described in some of the majestic passages of the latter part of the book of Isaiah and other parts of the prophetical books.

This is borne out by listening to what Hopgood has to tell us about his observations among the Tonga people.

The name LesalLeza is used to indicate God among a number of peoples in Zambia and Zaire, such as the Bemba, Lamba, Kaonde, Lala, and the Yeye of the northern Kalahari. Another people who seems to have similar views about God, is the Nandi of East Africa, who make daily prayers to Assista, the Supreme God (McVeigh, 1974:109). The Chagga of Tanzania believe that Ruwa punishes a disobedient child, a thief and a traitor to his tribe (McVeigh, 1974:93).

\subsubsection{A personal God}

That Leza is conceived of as personal, is indicated by more than one observation of Hopgood. In the first place he is sometimes called Father: Leza ngutateesu (Leza is our Father). Personal characteristics, such as anthropopathisms, are also ascribed to him; he is said sometimes to become angry (Hopgood, 1950:64, 65).

His personal character is also attested to by the names he is referred by: Cilenga (Creator), Lubumba (Moulder), Simalelo (Master), Munamazuba (Ancient One, with the same meaning as found in Daniel 7:22, which is also expressed by the Zulu name Simakade), Syatwaake (Owner), Mutalabala (the Omnipresent), Ciyobolola (Preserver), Civuna (Deliverer), Keemba (the Angry One). To be honest, one has to concede that Smith himself, who also stayed with the Tonga people for a number of years, is of the opinion that it is not fully clear whether Leza is to be conceived of as $I t$ or He, although, when saying Leza rains or Leza falls, they invariably use personal rather than impersonal class prefixes (McVeigh, 1974:12, 17).

\subsubsection{The transcendent Creator}

Hopgood (1950:72) says:

I have not found that Leza is ever thought of as father in any anthropomorphic and physical sense. Leza ... is spirit and not body, and as such is commonly thought of as sexless, though there seem to be traces of an idea that he combines both male and female characteristics. In describing the way in which he brought the first human beings into the world, the word commonly used is bumba - the verb used of the potter's activities - to mould, fashion, form. 
The same idea of Lesa/Leza as the transcendent Creator is found among other peoples who use this name for God, such as the Lamba and Kaonde (Hopgood, 1950:76). The Nuer concept of God also closely corresponds to this, although the Nuer are not related to the Tonga (McVeigh, 1974:144).

This concept is the more striking when one compares it with the concept found among the Southern African tribes, among whom the general idea exists that the first men emerged from the earth or from a thicket of reeds (inter alia Bleek, 1952:1; Smith, 1950:120).

\subsubsection{A God who is involved in what happens on earth}

Perhaps the most distinguishing feature of the Tonga idea of God is the fact that according to them Leza is intimately involved in what happens among men. He is not the Deus absconditus, the Deus otiosus who represents the African concept of God in general.

Of the Tonga idea of Leza. Hopgood $(1950: 62,63)$ writes:

Whatever exists owes its existence to Leza, and whatever happens is due to his activity, even though it may often baffle one to discover any other reason why a thing should happen.

The Tonga seem indeed to have very little idea of secondary causes. Hence they speak of all events, both in the realm of nature and in human life and experience, as brought about directly by Leza.

This is a case of very close correspondence between the Tonga and the Old Testament idea of God (Eichrodt, 1967, 1I:176; Von Rad, 1965:151).

\subsubsection{Sacrifices and prayers}

While among most other peoples in Southern Africa no sacrifices are offered to God, and prayers only in exceptional cases, in the case of Leza sacrifices are often offered to him. Although prayers are usually addressed to the ancestor spirits (mizimu), they are often spontaneously addressed directly to Leza, whether in the case of a request or as an expression of gratitude - which latter is rare indeed in Africa (see Hopgood, 1950:67,74).

\subsubsection{Omnipresence}

This idea is already expressed in the name Mutalabala, the Omnipresent One Hopgood relates the story of a young Tonga man who went to visit his Lozi mother in Barotseland, and when she, from the background of her Lozi idea of 
God, expressed her amazement at the idea that God was to be found among the Tonga too, he answered that Leza is everywhere.

He is like the sun. If you can find a land where the sun is unknown, there only may you expect to find that the inhabitants know nothing of God (Hopgood, 1950:72).

\subsubsection{Leza and human behaviour}

Whereas among most African peoples, God is not supposed to be concerned with human behaviour in general, and often only with matters that concern cosmic order, Leza is, according to Hodgood, supposed to be concerned with moral right and wrong among people. Hopgood relates the incident of a fireside discussion about God. "'How is it,' a young man asked, 'that we mortals, knowing that there is a God above, continue to sin?'" (Hopgood, 1950:71).

A Bemba women told me that often, when a child is disobedient, it is told, 'Lesa alekumona' (God can see you).

It should be pointed out that the Tonga/lla do not seem to be consistent in their views about Leza, as has been demonstrated in paragraph 2.4. Some see him as the uninvolved, indulgent cosmic Grandfather.

\subsection{Katonda and the Lubare: polytheism}

Whereas in Southern Africa, up to Malawi, Zaire and Zambia, the idea of God is usually monotheistic, the concepts of the Baganda and neighbouring peoples are rather crudely polytheistic. According to Thomas (1950:204-206) this polytheism developed only during the eighteenth and nineteenth centuries, as a result of the threat from the Luo people who invaded Buganda from the north. This threat lead to the erection of a number of shrines to spirits of mighty ancestors, balubare, whose status in the course of time were enhanced to that of secondary deities. When Alexander Mackay arrived in Uganda in the seventies of the previous century, he found this cult firmly established (Kropholler, 1890:143f.).

Since God is conceived of by most peoples as being part of the cosmos and even of the family of humanity, and the essential difference between God and man because of that becomes vague, tribal spirits of chiefs with exceptional prestige could easily cross the threshold to divinity in the mind of the people.

This polytheism is a model for the concepts of deity in many other African cultures, especially to the north of Uganda and in West Africa, as for instance among the Yoruba and Kono (Smith, 1950:224-266) and the Ashanti (McVeigh, 1974:34, 35). Possibly the Tswana 'gods' Cosa (Tshosa ?), the god of destiny, and Nape, the god of divination, fall under this category (McVeigh, 1974:36). 
It seems as if in general, where society developed an intricate hierarchical system, this system was projected onto the concept of God and polytheism developed. Where there were no similar developments, monotheism is the common concept.

\section{Conclusion}

From this overview one has to conclude that there is a vast difference between the Old Testament concept of God and the traditional concepts of most African peoples. The concepts of African peoples reflect the way natural man responded to God's revelation in creation and in their consciences. The Old Testament reflects God's special revelation to his people Israel, which cannot be put on the same level as the religion of any other people (Deut. 4:32-40).

\section{Bibliography}

BERGLUND, AXEL-IVAR. 1976 Zulu Thought-Patterns and Symbolism London : C Hurst \& Co $402 p$

BLEEK, Wm. H I 1952. Zulu Legends Edited by Engelbrecht, J A Pretoria : Van Schaik $46 \mathrm{p}$

CULLEN YOUNG, T 1950. The Idea of God in Northern Nyasaland (In Smith, E W ed African Ideas of God. London: Edinburgh House Press p. 36-58)

DANEEL, ML 1970. The God of the Matopo Hills An Essay on the Mwari Cult in Rhodesia The Hague : Mouton. $95 \mathrm{p}$.

HELBERG, JL 1976. A Startingpoint and Method for Old Testament Study. Res Theological Bulletim, 4 (2) 1-14.

HOPGOOD, C R 1950 Conceptions of God amongst the Tonga of Northern Rhodesia (In Smith, E W. ed African Ideas of God London. Edinburgh House Press p. 61-75)

HUNTER, Monica 1961. Reaction to Conquest Effects of Contact with Europeans on the Pondo of South Africa. London: Oxford University Press $582 \mathrm{p}$

INKATHA 1980 Ubuntu-Botho, Vols. I \& Il Pietermaritzburg . KwaZulu Booksellers. $40 \& 81 \mathrm{p}$

JACOB, E 1958 Theology of the Old Testament London: Hodder \& Stoughton. $368 \mathrm{p}$ JUNOD, H A 1962. The Life of a South African Tribe, Part II Mental Life New York University Books Inc $660 \mathrm{p}$

KEIL, C.F 1875. Biblical Commentary on the Old Testament, Vol I Ex. 4:22, 23. Grand Rapids Eerdmans. p. 458

KRITZINGER, J J. 1988 Die onvoltooide sendingtaak in Suid-Afrika Pretoria : ISWEN $116 \mathrm{p}$.

KROPHOLLER, A J. 1890 (Vertaler). Mackay, de held van Uganda Amsterdam : Jacques Dusseau $458 \mathrm{p}$

KUPER, Hilda 1947. An African Aristocracy Rank Among the Swazi London : O UP $251 \mathrm{p}$

MBITI, J S. 1970 . Concepts of God in Africa. London: S. P. C. K $348 \mathrm{p}$

MCVEIGH, M J. 1974 God in Africa Conceptions of God in African Traditional Religion and Christianity. Cape Cod : Claude Stark 235 p

SCHOLTZ, L 1994 Regses alleen in hulle Godsbeskouing Die Beeld, 1994-03-08

SCHUTTE. A G. 1978 Mwali in Venda Some Observations of the Significance of the High God in Venda History Journal of Religion in Africa, 9:109-122 
SETILOANE, G.M. 1976. The Image of God among the Sotho-Tswana Johannesburg :

Skotaville Publishers. $298 \mathrm{p}$

SETLOANE, GM 1986. African Theology. Johannesburg: Skotaville Publishers $50 \mathrm{p}$

SMITH, E.W ed. 1950. African Ideas of God. London : Edinburgh House Press. $308 \mathrm{p}$

TEMPELS, P. 1946. Bantoe-filosofie. Antwerpen . De Sikkel 115 p.

THOMAS, H.B. 1950. The Doctrine of God in Uganda. (In Smith, E. W ed. African Ideas of God. London : Edinburgh House Press. p. 201-207.) 